\title{
ANALYSIS OF THE ABILITY TO PUSH HOVERCRAFT VEHICLES TO SUPPORT ARMY SWAMP OPERATIONS
}

\author{
Endia Muhamat Nur ${ }^{1}$, Moch. Ma'ruf ${ }^{1 *}$, Agus Mulyono $^{2}$ \\ ${ }^{1}$ Department of Mechanical Engineering, University of Merdeka Malang \\ ${ }^{2}$ Department of IFV Engineering, Poltekad, Malang \\ *Email corresponding author: moch.maruf@unmer.ac.id
}

\begin{abstract}
A hovercraft is an amphibious vehicle that works on an air cushion, capable of traveling on land and water terrains. This vehicle is driven by two systems, namely the lifting system and the propulsion system. The propulsion system functions to produce a thrust that will drive the hovercraft vehicle forward. The thrust is influenced by engine speed, transmission, shaft rotation, fan design, air flow speed, flow rate mass, and air discharge. This research method is carried out by varying the engine speed, starting from 1000rpm, 1200rpm, 1400rpm, 1600rpm, 1800rpm, 2000rpm, 2200rpm rotation. The results of the research and data processing showed that the higher the rotation of the shaft, the greater the thrust generated. Where at a minimum engine speed of $1000 \mathrm{rpm}$, the shaft rotation of $436 \mathrm{rpm}$ produces a thrust of 11.794 Newton. Whereas at the maximum $2200 \mathrm{rpm}$ engine speed, the $1060 \mathrm{rpm}$ shaft rotation produces a thrust of 87.664 Newton.
\end{abstract}

Keywords: Engine speed, shaft rotation, exit air velocity, mass flow rate, air discharge, thrust.

\section{INTRODUCTION}

Hovercraft is an organic TNI-AD vehicle that functions to transport personnel and materials from one island to another. Hovercraft is an amphibious vehicle that works on an air cushion, capable of running on land and water terrains. This vehicle is driven by two systems, namely the lifting system and the propulsion system. The lifting system is functioned to pump air into the concrete so that the vehicle is lifted (hovered), so that the vehicle does not have great friction against the surface of the water or the ground when driving. The propulsion system serves to push the vehicle when it has been lifted so that the vehicle can move forward.

The performance of the hovercraft vehicle to carry out its functions is affected by several forces, namely the thrust force, lift force, drag force and weight force. If the influencing forces meet the requirements, the hovercraft will be able to perform its function.

The most important thing for moving a hovercraft to be able to move is that it needs a large thrust to fight gravity, friction and drag. To get a large thrust, it is influenced by engine speed, driving fan rotation, fan dimensions, air exit velocity, air flow rate and mass flow rate.

For this reason, in order to get maximum performance results, the author tries to analyze this vehicle with the title "Analysis of the Ability to Push Hovercraft Vehicles to Support Army Swamp Operations".

Based on the background above, the problem formulations in this study are:

1. How is the effect of shaft rotation on the thrust air speed generated by the axial fan?

2. How does the shaft rotation affect the fan thrust?

3. How does shaft rotation affect fan thrust? 
4. How does transmission efficiency affect?

To clarify the scope of the problems discussed, the authors need some limitations to be described, including:

1. Calculating the mass flow rate.

2. Calculating the air discharge.

3. Calculating the axial fan thrust.

4. Calculating hovercraft drag.

5. Calculating the thrust of the hovercraft.

\section{METHODOLOGY}

In the implementation of this thesis, the implementation is divided into several stages of writing starting from observing functions, working methods, collecting data, and testing to find out the results of making this bicycle.

1. Place of manufacture of tools

2. Tool upgrade time.

3. Waktu Pengambilan data.

\section{Research Methodology}

In this research method aims to analyze the propulsion ability of a hovercraft vehicle so that the vehicle is able to go at the desired speed.

\section{Variables}

The variables used in this study are as follows:

1. Independent variable

The independent variable is the variable whose amount is determined by the author, namely the engine speed of 1000-2200 Rpm.

\section{Dependent variable}

The dependent variable is a variable whose magnitude cannot be determined by the author but the amount depends on the independent variable. In this planning the bound variables are:
a. Axial fan shaft rotation
b. Air Velocity Exiting the fan housing.
c. Fan pushing force.
d. Fan drive power.

\section{Tools and Materials Used.}

In the implementation of this research, the tools used are hovercraft vehicles and aids for data collection.

\section{Hovercraft specification data:}
a. Vehicle weight without driver: $130 \mathrm{~kg}$
b. Engine type: $110 \mathrm{cc} / 4$ stroke
c. Lifting engine type: $150 \mathrm{cc} / 4$ stroke
d. Pusher / lift fan type: Axial
e. Vehicle body material: plywood
f. Material of skirt: Taslan cloth

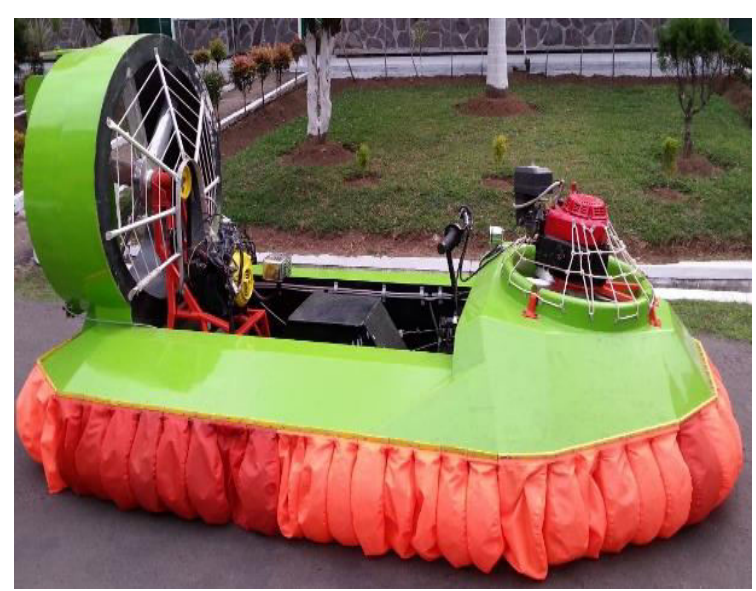

Figure 1. Hovercraft Vehicle.

\section{Material}

1. The propulsion engine functions as a drive for the hovercraft propulsion system. 


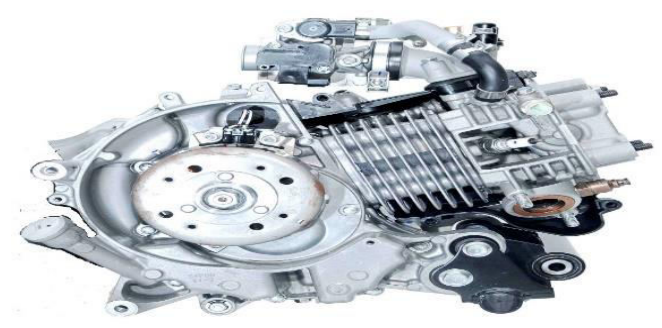

Figure 2. Driver engine.

\section{Engine specification:}

a. Engine type: Yamaha

b. Engine capacity: $110 \mathrm{cc}$

c. Cylinder: single

d. Max power: $7.14 \mathrm{~kW}$ or $8000 \mathrm{rpm}$

2. Kipas Aksial. Berfungsi sebagai penggerak kendaran hovercraft untuk melawan gaya berat,gaya hambat dan gaya gesek agar kendaraan mampu melaju.

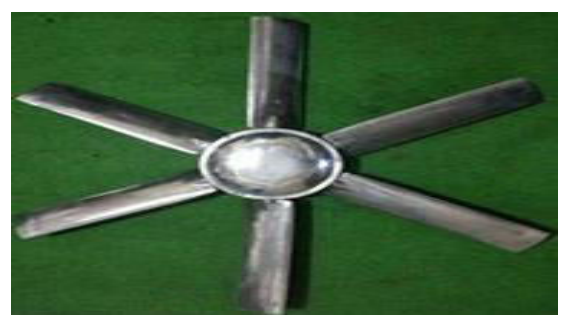

Figure 3. Axial fan

\section{Fan specification:}

a. Fan type: Axial

b. Diameter: 32 inches $=0.812$ meters

c. Angle of attack: 180

d. Number of blades: 6 pieces

3. Pully. Is a mechanical motion tool that is used as a support for the movement of a belt or circle belt to carry out a groove force that functions to deliver a power. The workings of the pully are often used to change the direction of the applied force and to deliver rotation.

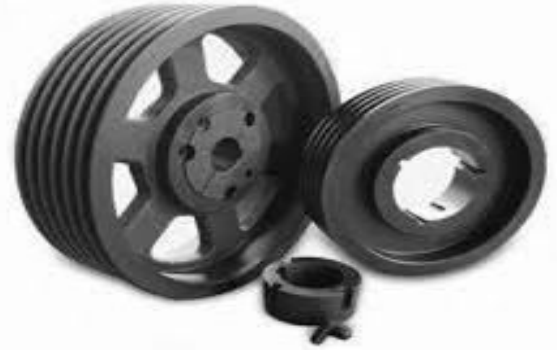

Figure 4. Pully

4. Timing belt. Serves as a rotation successor from the engine crankshaft to the axial fan shaft.

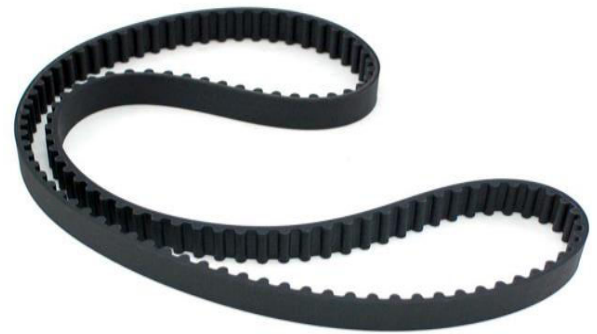

Figure 5. Timing belt.

5. Axis. Serves to continue power together with engine speed.

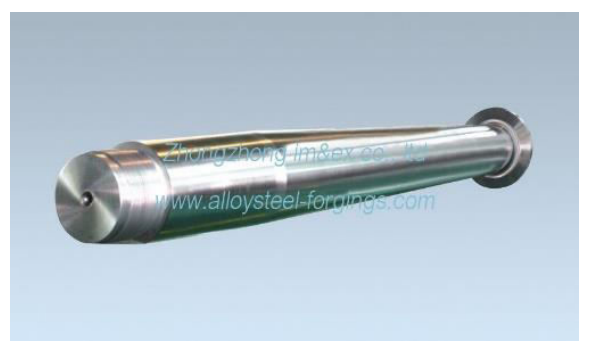

Figure 6. Axis

\section{Auxiliary Equipment}

The auxiliary equipment that is meant here is a tool used to measure test parameters and also other tools needed to help carry out research. The selection of measuring instruments used in this study is based on the availability of the tools, the ease of operation and the accuracy of their measurements. The assistive equipment used during this research are: 
1. Anemometer. Sebagai alat ukur kecepatan udara keluar yang dihasilkan oleh kipas pendorong dan pengukur kecepatan hovercraft melaju.

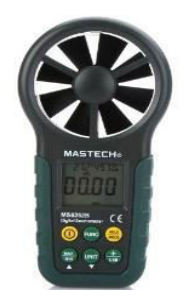

Figure 7. Anemometer

2. Tachometer. Serves to measure the engine speed of the hovercraft booster.

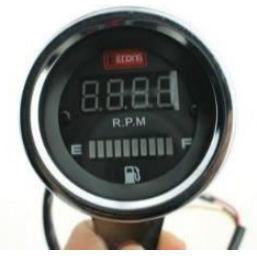

Figure 8. Tachometer

\section{Data Retrieval Step}

a. Plunger Engine Start.

b. Measure the ambient air temperature and humidity.

c. Measure the atmospheric pressure.

d. Rotation Settings (set the engine speed from $1000 \mathrm{rpm} ; 1200 \mathrm{rpm} ; 1400 \mathrm{rpm}$; 1600 rpm; 1800 rpm; 2000 rpm; 2200 rpm).

e. Measure the axial fan shaft rotation (from engine speed of $1000 \mathrm{rpm} ; 1200 \mathrm{rpm}$; 1400 rpm; 1600 rpm; 1800 rpm; 2000 rpm; 2200 rpm).

f. Measure the speed of the air coming out of the fan housing (from engine speed of 1000 rpm; 1200 rpm; 1400 rpm; 1600 rpm; 1800 rpm; 2000 rpm; 2200 rpm).

\section{Data processing and analysis step}

After collecting data from the hovercraft propulsion system testing, calculations are made regarding the fan blade, mass flow rate, air flow rate, ipas thrust, fan thrust, and transmission efficiency using the formula on the theoretical basis. The results of the calculation of the test are written in table form using excel, it can produce a graph of the relationship between the rotation of the shaft to the speed of the exhausted air, the rotation of the shaft to the thrust of the fan, the rotation of the shaft to the thrust of the fan, and the efficiency of the transmission. After producing an observation table and graph, it can be compared, analyzed and conclusions drawn.

Table 1. Data Retrieval Table

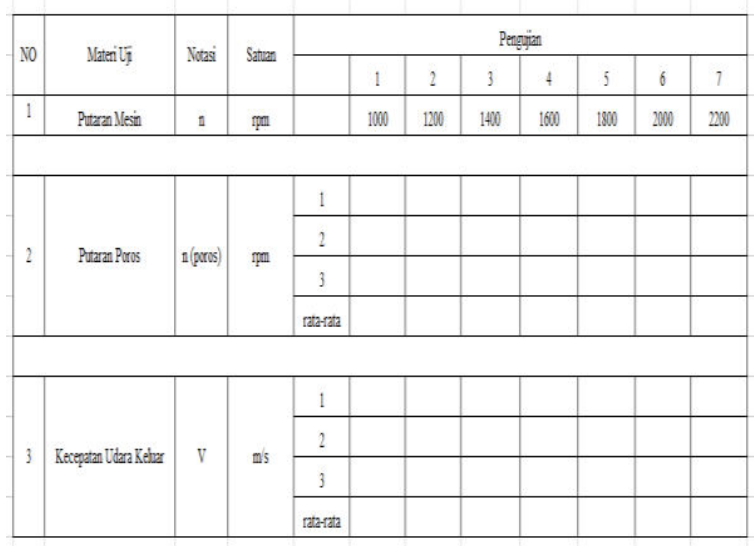

\section{Installation of Testing Tools}

The installation scheme to be implemented is as shown in the following figure: 


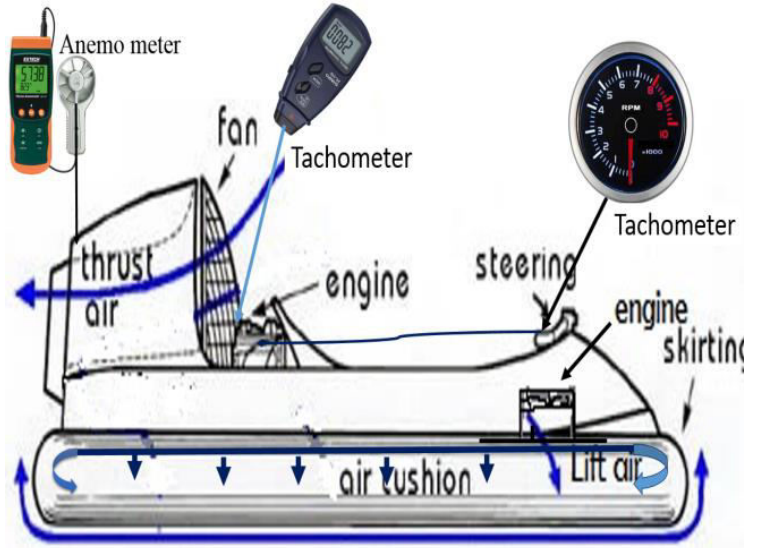

Figure 9. Testing Installation Scheme

\section{Flow diagram}

To simplify the making of the tool, a global system block diagram design is needed, for the flow chart it can be shown in the image below.

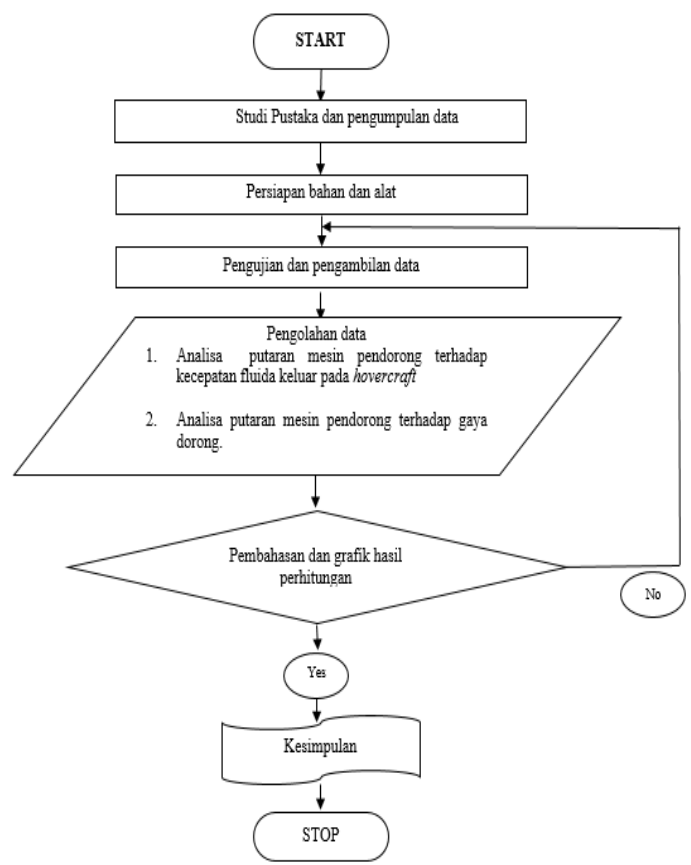

\section{RESULT AND DISCUSSION}

Based on data collection, data processing is carried out, which aims to determine the thrust generated by varying the engine speed so that the shaft rotation and the resulting air exit velocity will be different to produce fan thrust.

\section{Preliminary Research Data}

The initial data obtained are as follows:

1. Retrieval of data by varying the engine speed.

2. Retrieval of fan shaft rotation data.

3. Retrieval of air speed data out of the fan housing.

Table 2. Preliminary Retrieval Data

\begin{tabular}{|c|c|c|c|c|c|c|c|c|c|c|c|}
\hline \multirow{2}{*}{10} & \multirow{2}{*}{ Vateritji } & \multirow{2}{*}{ Notasi } & \multirow{2}{*}{ Stan } & \multicolumn{8}{|c|}{ Pergogian } \\
\hline & & & & & 1 & 2 & 3 & 4 & 5 & 6 & 7 \\
\hline 1 & Ptran Yesin & 1 & mp & & 1000 & 1200 & 1400 & 1600 & 1800 & 2000 & 2200 \\
\hline \multirow{4}{*}{2} & \multirow{4}{*}{ PuternPoros } & \multirow{4}{*}{$\mathrm{a}$ (poros) } & \multirow{4}{*}{ mp } & 1 & 450,8 & 548 & 693,7 & 751,6 & 873,8 & 935,6 & 1054 \\
\hline & & & & 2 & 4373 & 524 & 708,1 & 720,7 & 856,1 & 923,7 & 1053 \\
\hline & & & & 3 & 421.8 & 531,1 & 649,5 & 7866 & 853,8 & 934,1 & 1071 \\
\hline & & & & tatartath & 436,6333 & $534,366^{\circ}$ & 683,76667 & 75296667 & 86123333 & 931,1333 & 1059,3333 \\
\hline \multirow{4}{*}{3} & \multirow{4}{*}{ Kesepptan Ideara Keliar } & \multirow{4}{*}{$V$} & \multirow{4}{*}{$\mathbb{m s}$} & 1 & 3,7 & 52. & 6,7 & 69 & 7,8 & 9.1 & 10.8 \\
\hline & & & & 2 & 3.5 & 49 & 6.5 & 6,6 & 7,5 & 93 & 109 \\
\hline & & & & 3 & 33 & 53 & 6,6 & 69 & 7,8 & $9 ?$ & 10,6 \\
\hline & & & & thatrata & 3.5 & 5,133333 & 6,6 & 6,8 & 7,7 & $9 ?$ & 10,766660 \\
\hline
\end{tabular}

\section{Calculating the axial fan blade:}

1. Calculating the speed of the road blade:

$u=\frac{\pi \times \mathrm{D} \times \mathrm{n}}{60}$

$$
=\frac{3,14 \times 0,813 \mathrm{~m} \times 436 \mathrm{rpm}}{60}
$$

$=18,545 \mathrm{~m} / \mathrm{s}$

2. Calculating relative velocity:

$$
\begin{aligned}
\mathrm{W} & =\frac{\mathrm{u}}{\sin \beta} \\
& =\frac{18,545 \mathrm{~m} / \mathrm{s}}{\sin 20} \\
& =19,391 \mathrm{~m} / \mathrm{s}
\end{aligned}
$$

3. Calculating absolute velocity:

$\mathrm{c}=\mathrm{w} \mathrm{x} \cos \beta$

$$
=16,931 \mathrm{~m} / \mathrm{sx} 0,408
$$

$$
=6,909 \mathrm{~m} / \mathrm{s}
$$


Determine the Cross-Sectional Area of the

Axial Fan.

$$
\begin{aligned}
\mathrm{A} & =\frac{1}{4} \cdot \pi \cdot \mathrm{D}^{2} \\
& =\frac{1}{4} \cdot 3,14 \cdot(0,8128)^{2} \\
& =0,518 \mathrm{~m}^{2}
\end{aligned}
$$

Calculating the density of air.

$$
\begin{aligned}
& \rho=\frac{\mathrm{P}}{\mathrm{R} \cdot \mathrm{T}} \\
& \rho=\frac{9,81 \times 10^{4} \mathrm{~N} / \mathrm{m}^{2}}{\left(287 \frac{\mathrm{j}}{\mathrm{kg}} \cdot \mathrm{k}\right)\left(273+25^{0} \mathrm{k}\right)} \\
& \rho=1,147\left(\mathrm{~kg} / \mathrm{m}^{3}\right)
\end{aligned}
$$

\section{Calculates the mass flow rate.}

Where to calculate the air mass flow rate required the density of air, the crosssectional area of the fan and the solute velocity of the fan, the calculations obtained for the air mass flow rate are as follows:

$$
\begin{aligned}
\dot{\mathrm{m}} & =\rho \cdot \mathrm{A} \cdot \mathrm{c} \\
& =1,147 \mathrm{~kg} / \mathrm{m}^{3} \times 0,518 \mathrm{~m}^{2} \times 5,665 \mathrm{~m} / \mathrm{s} \\
& =3,369 \mathrm{~kg} / \mathrm{s}
\end{aligned}
$$

\section{Calculating water charge}

Where to calculate the air flow rate, the mass flow rate and density of the air are needed, the calculations obtained to get the air flow rate are as follows:

$$
\begin{gathered}
\mathrm{Q}=\frac{\dot{\mathrm{m}}}{\rho} \\
=\frac{3,369 \mathrm{~kg} / \mathrm{s}}{1,147 \mathrm{~kg} / \mathrm{m} 3} \\
=2,937 \mathrm{~m}^{3} / \mathrm{s}
\end{gathered}
$$

\section{Calculating the axial fan thrust.}

Where the thrust of the axial fan functions to push the hovercraft vehicle that has been lifted due to the lift, to calculate the thrust it requires the mass flow rate of air and the velocity of the air out, then the following calculations are generated:

$$
\mathrm{F}_{\text {fan }}=\dot{\mathrm{m}} \times \mathrm{C}_{2}
$$

$$
\begin{aligned}
& =3,369 \mathrm{~kg} / \mathrm{s} \mathrm{x} 3,5 \mathrm{~m} / \mathrm{s} \\
& =11,794 \mathrm{~N}
\end{aligned}
$$

\begin{tabular}{|c|c|c|c|c|c|c|c|c|c|}
\hline \multirow{2}{*}{ Naterilui } & \multirow{2}{*}{ Notasi } & \multirow{2}{*}{ Satuan } & \multicolumn{7}{|c|}{ Pengyian } \\
\hline & & & 1 & 2 & 3 & 4 & 5 & 6 & 1 \\
\hline 1. Pitaran Mesin & $n$ & rpm & 1000 & 1200 & 140 & 1600 & 1800 & 2000 & 2200 \\
\hline 2 Putaran poros & $n$ & $\mathrm{rpm}$ & 436 & 538 & 684 & 753 & 861 & 93! & 1060 \\
\hline 3 / Keccostan Udara Kevara & $G$ & $\mathrm{~m} / \mathrm{s}$ & 3,5 & 51. & 6,5 & 68 & 1,1 & 9.2 & 10,7 \\
\hline 4 Massa lenis Sdaga & p & $\mathrm{kg} / \mathrm{m}^{3}$ & 1,1402 & 1,1402 & 1,1,402. & 1,1402 & 1,1402 & $1,1,402$ & 1,1402 \\
\hline 5 Kecepataten keling & $v$ & $\mathrm{~m} / \mathrm{s}$ & 18,4593 & 82,88465 & 2099999: & $32,3300=$ & 36623956 : & 3960151. & 45,08873 \\
\hline 6 Kecepatan reatif & $w$ & $\mathrm{~m} / \mathrm{s}$ & 19399188 & 823928561. & 30,921212: & 33,99102 & 3829456 & 4, 1,90789 & 47,154: \\
\hline 7 Kecepotian Absolut: & c & $\mathrm{m} / \mathrm{s}$ & $5,6655.4$ & 6990976 & 88875.19 & 97848067 & 11187836 & 120969 & 13,7326 \\
\hline 8 Luas Penampangeg Kipas & $A$ & $m^{2}$ & 0,518005 & $0,0,18065$ & 0,518005 & 05,18065 & 05180050 & 0,586005 & $0,0,18605$ \\
\hline 9 L Lijulligan Nassa & m & lels & 3369914 & 4,458289 & 5,28074 & 5800058 & 66518007 & 7,195849 & 8,8999 \\
\hline 10 Degit doara & Q & $\mathrm{m}^{3} / \mathrm{s}$ & 2,937974 & 3,065298 & 4,6091.16 & 5,0747 & 50018065 & 6,275318 & $87,4278$. \\
\hline 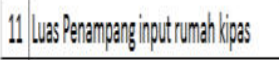 & $A_{1}$ & $m^{2}$ & 0,65585 & 0,65385 & 0,65585 & 0,63585 & 0,63585 & 0,65585 & 0,65355 \\
\hline 12. Las Perampangang Outoput Ruman Kipas & A & $m^{2}$ & 0,458006 & 60,45006 & 0,558006 & 0,455006 & 0,558060 & 0,558006 & 60,45506 \\
\hline 13 Gaplacorong (Kass & fitan & N & 11,997 & 2120027 & 34,46385 & 395,7639 & 51242026 & 66201081 & 18766444 \\
\hline 14 Daplaborong & $P$ & wath & 41,2815:5 & 108157. & 223365 & 26911195 & 3945653 & 6095656: & 9380,063 \\
\hline 15 Ettisensitransmisi & 1 & $\%$ & 0,36 & 0,48333 & $0,88557$. & 0,07065 & 0,78333 & 0,4655 & 0,48888 \\
\hline
\end{tabular}

\section{Calculate fan thrust}

Where to calculate the fan thrust, it takes the force and velocity of the air out. The calculations are as follows:

$$
\begin{aligned}
\mathrm{P} & =\mathrm{F} \times \mathrm{C} 2 \\
& =11,749 \mathrm{~N} \times 3,5 \mathrm{~m} / \mathrm{s} \\
& =41,281 \text { Watt }
\end{aligned}
$$

\section{Efficiency of transmission}

Calculating the efficiency of the transmission, namely the ratio of the shaft rotation and engine speed. The calculations are as follows:

$$
\begin{aligned}
\eta= & \frac{n(\text { poros })}{n(\text { mesin })} \times 100 \% \\
& =\frac{436 \mathrm{rpm}}{1000 \mathrm{rpm}} \times 100 \% \\
& =43,6 \%
\end{aligned}
$$

Table 3. Calculation results and data processing. 


\section{DISCUSSION}

Graph of the Relationship between Fan Shaft Rotation and Air Speed Out.

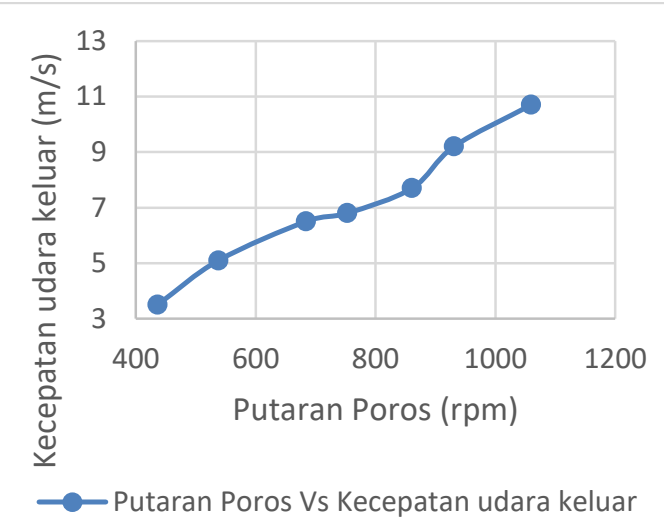

Figure10. Graph of the relationship between fan shaft rotation and air speed out.

In Figure 10, the graph of the relationship between the rotation of the shaft and the velocity of the air out. The minimum shaft rotation is $436 \mathrm{rpm}$ and produces an exit air velocity of $3.5 \mathrm{~m} / \mathrm{s}$, while at a maximum shaft rotation of $1060 \mathrm{rpm}$ it results in an exit air velocity of $10.7 \mathrm{~m} / \mathrm{s}$. So from the results of data retrieval the higher the rotation of the shaft, the higher the velocity of the resulting air out.

Graph of Fan Shaft Rotation Relationship to Fan Push Force.

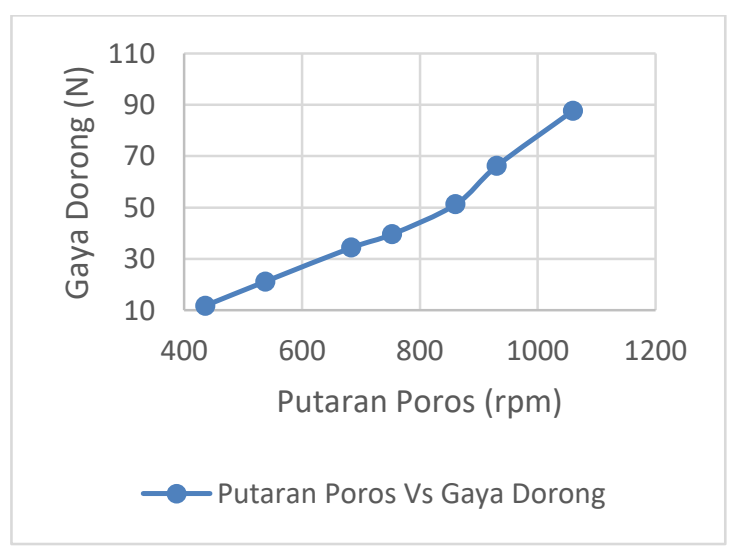

Figure 11. Graph of the relationship between shaft rotation and fan thrust.
In Figure 11. graph of the relationship between shaft rotation and fan thrust. At a minimum shaft rotation of $436 \mathrm{rpm}$ produces a thrust of 11.794 Newton, while at a maximum shaft rotation of $1060 \mathrm{rpm}$ it produces a thrust of 87.664 Newton. From the results of the discussion, the higher the rotation of the shaft, the greater the thrust generated by the fan.

Graph of Fan Shaft Rotation Relationship to Thrust.

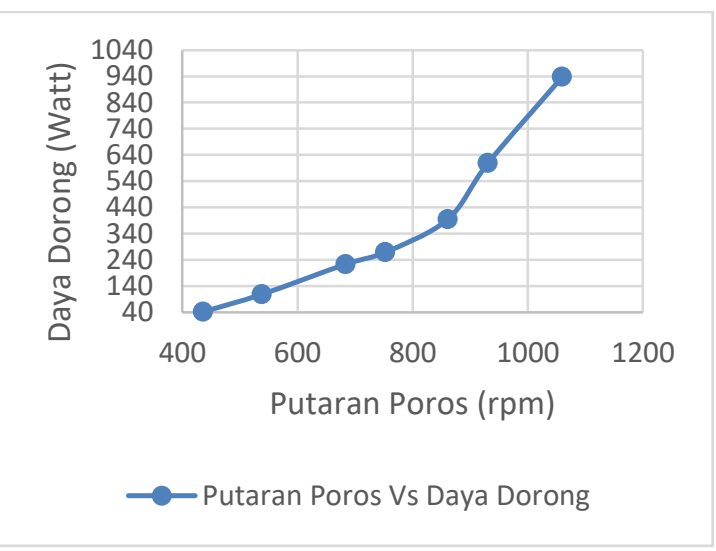

Figure 12. Graph of the relationship between shaft rotation and fan thrust.

In Figure 12. a graph of the relationship between shaft rotation and fan thrust. At a minimum shaft rotation of $436 \mathrm{rpm}$ it produces a thrust of 41 Watt, while at a maximum shaft rotation of $1060 \mathrm{rpm}$ it produces a thrust of 938.006 Watt. From the results of the discussion, the higher the rotation of the shaft, the greater the thrust generated by the fan. 
Graph of Transmission Efficiency

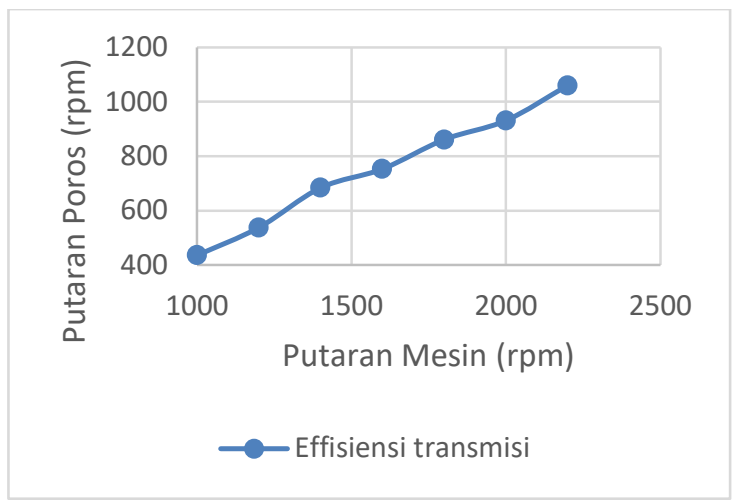

Figure 13. Graph of the relationship between the rotation of the shaft and the velocity of the air out.

In Figure 13. the graph of the relationship between engine speed and shaft rotation results in transmission efficiency. At 1000rpm engine speed produces 436rpm of shaft rotation. While at 2200rpm engine speed produces 1060 engine speed, so the efficiency that occurs is between $43 \%-48 \%$.

\section{CONCLUSION}

Based on the results of research and analysis of calculations about the effect of engine speed on the thrust capability are as follows:

1. The higher the shaft rotation, the higher the air speed generated by the fan.

2. The higher the rotation of the shaft, the greater the thrust it produces.

3. The highest thrust is generated at the shaft rotation of $1060 \mathrm{rpm}$ which is equal to $87.664 \mathrm{~N}$.

4. The higher the rotation of the shaft, the greater the thrust it produces.

5. The greatest thrust is generated at 1060 rpm rotation of 938 Watt.

6. Transmission efficiency $43 \%-48 \%$

\section{REFERENCES}

1. Dietzel Fritz, 1990, Turbin Pompa dan Kompresor. Erlangga, Jakarta.

2. Hawking Stephen, 1988. Ringkasan Fisika Terapan.

3. L. Steeter Victor, 1979, Fluid Mechanics. Megraw-Hill, United States of America. 